\title{
PENGEMBANGAN SISTEM PELAPORAN HAZARD DAN MANAJEMEN RISIKO KESELAMATAN BERBASIS WEB PADA BANDAR UDARA
}

\section{Triyani Retno Putri Sari Dewi}

Politeknik Penerbangan Indonesia Curug

e-mail: triyaniretno@ppicurug.ac.id

\begin{abstract}
Abstrak: Pelaporan hazard adalah hal yang sangat penting dalam sistem manajamen keselamatan penerbangan. Hazard yang teridentifikasi melalui laporan dapat digunakan untuk mengelola risiko keselamatan. Dengan kemajuan teknologi, hazard dapat lebih cepat dilaporkan secara daring sehingga dapat segera dilakukan mitigasi. Penelitian ini bertujuan untuk mengembangkan sistem pelaporan hazard dan manajemen risiko keselamatan berbasis web untuk meningkatkan budaya pelaporan pada bandar udara dan mengelola risiko keselamatan dengan cara yang lebih efektif. Penelitian ini menggunakan metode penelitian berbasis desain dengan empat tahap yaitu analisis masalah, pengembangan solusi, pengujian dan perbaikan produk, dan refleksi. Hasil pengujian penerimaan pengguna menunjukkan bahwa desain tersebut efektif dan bermanfaat untuk melaporkan hazard dan mengelola risiko keselamatan.
\end{abstract}

Kata Kunci: bandara, hazard, keselamatan, manajemen risiko, sistem pelaporan

Abstract: $\quad H a z a r d$ reporting is very important in aviation safety management system. Hazards identified through the report can be used to manage safety risks. With advances in technology, hazards can be reported online more quickly so that mitigation can be carried out immediately. This study aims to develop a web-based hazard reporting and safety risk management system to improve the reporting culture at airports and manage safety risks in a more effective manner. This study uses a design-based research method with four stages, namely problem analysis, solution development, product testing and improvement, and reflection. The results of user acceptance test show that the design is effective and useful for reporting hazards and managing safety risks.

Keyword: $\quad$ airport, hazard, online reporting system, risk management, safety 


\section{Pendahuluan}

Airports Council International World Safety \& Technical Standing Committee (2014) menyatakan bahwa runway incursion, excursion, dan confusion menimbulkan beberapa bahaya penerbangan terbesar, yang berpotensi menciptakan konsekuensi yang sangat serius. Untuk memitigasi konsekuensinya, setiap hazard yang ditemukan atau peristiwa keselamatan yang terjadi di sekitar bandara harus segera dilaporkan agar tindakan pencegahan/perbaikan dapat diambil dan diselesaikan. Namun, kesadaran dan kemauan untuk melaporkan hazard atau peristiwa keselamatan masih kurang yang dibuktikan dengan sedikitnya laporan yang diterima oleh manajer keselamatan bandara. Berdasarkan hasil pengamatan, hal ini disebabkan oleh kurangnya kesadaran akan keselamatan dan tidak tersedianya sistem pelaporan yang mudah untuk digunakan. Sistem pelaporan hazard yang ada di sebagian besar bandara masih menggunakan formulir pelaporan berbasis kertas. Begitu pula dengan manajemen risiko keselamatan yang dilakukan oleh manajer keselamatan yang tidak terintegrasi dengan suatu sistem dan tidak dapat diakses dari jarak jauh serta tidak dapat dimonitor oleh manajemen puncak.

Sejalan dengan kemajuan teknologi dan internet, telah terdapat beberapa penelitian pengembangan sistem pelaporan berbasis web. Nikitha et.al (2018) telah mengembangkan sebuah sistem pelaporan kejahatan daring yang bertujuan untuk menyediakan sistem pelaporan ke kantor polisi. Peters et.al (2008) juga telah mengembangkan sistem pelaporan daring untuk mengevaluasi program pendidikan orang tua multisitus pada daerah pedesaan. Model ebudgeting dan e-reporting system dalam pengelolaan keuangan dana desa juga telah dikembangkan oleh Setyawan et. al pada tahun 2017 yang bertujuan untuk mengendalikan dana desa secara efektif, efisien dan akuntabel. Namun, belum ditemukan studi penelitian tentang sistem pelaporan berbasis web di bidang penerbangan khususnya pada bandara. Oleh karena itu, studi penelitian tentang pengembangan sitem pelaporan hazard dan manajemen risiko keselamatan berbasis web untuk meningkatkan keselamatan bandara dianggap penting untuk dilakukan.

\section{Design-based research}

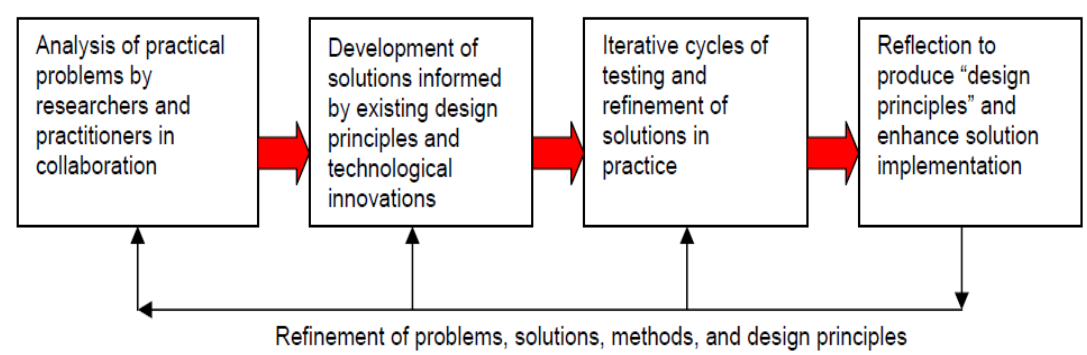

Gambar 1 : Penelitian berbasis desain 
Pengembangan Sistem Pelaporan Hazard Dan Manajemen Risiko Keselamatan Berbasis Web pada Bandar Udara

\section{Metode Penelitian}

Metode Penelitian pada penelitian ini adalah metode penelitian dan pengembangan yang bertujuan untuk menghasilkan produk sistem berbasis web untuk pelaporan hazard dan manajemen risiko keselamatan pada bandar udara. Adapun model penelitian yang digunakan adalah model Amiel \& Reeves (2008) seperti dapat dilihat pada Gambar 1.

\section{Prosedur dan teknik pengumpulan data}

Prosedur penelitian ini secara prinsip melalui beberapa tahapan yang terdiri dari: (1) analisis masalah; (2) pengembangan solusi berdasarkan prinsip desain yang ada dan inovasi teknologi; (3) pengujian dan perbaikan produk; dan (4) refleksi untuk menghasilkan prinsip-prinsip desain dan meningkatkan produk. Data dikumpulkan melalui tiga cara yakni melalui wawancara dengan Subject Matter Expert (manajer keselamatan bandara), pengamatan, tes penerimaan pengguna, dan juga kuesioner. Data yang terkumpul dianalisis secara kualitatif dan kuantitatif yang meliputi empat prosedur penelitian sebagai berikut:

\section{a. Tahap pertama}

Tahap pertama dimulai dengan analisis masalah oleh peneliti berkolaborasi dengan praktisi. Pada tahap ini peneliti melakukan gap analysis dengan membandingkan standar yang telah ditetapkan oleh International Civil Aviation Organization (ICAO) dengan prakteknya di lapangan. Peneliti mengacu pada ICAO Doc 9859 (2013) tentang Safety Management System, ICAO Runway Safety Handbook (2015), ICAO Doc 9870 (2007) tentang Manual on the Prevention of Runway Incursions, Indonesian Civil Aviation Safety Regulation (CASR) Part 19 tentang Sistem Manajemen Keselamatan, Peraturan Menteri Perhubungan Nomor PM 83 Tahun 2017 tentang CASR Part 139 tentang Bandar Udara serta peraturan dan literatur terkait lainnya tentang Sistem Manajemen Keselamatan. Sebuah daftar periksa tentang Identifikasi Hazard dan Manajemen Risiko Keselamatan yang terdapat pada Buku Pegangan ICAO Runway Safety Team diadopsi untuk menemukan celah tersebut. Daftar periksa dapat dilihat pada Tabel 1.

Peneliti mengamati praktek identifikasi hazard dan manajemen risiko keselamatan di divisi Sistem Manajemen Keselamatan dan juga melaksanakan wawancara dengan manajer keamanan bandara dan petugas lapangan. Peneliti juga mengamati pelaksanaan pertemuan Runway Safety Team yang membahas laporan hazard dari pemangku kepentingan di sekitar bandara yang diundang yang kemudian dibuat catatan lapangan sebagai sumber data.

b. Tahap Kedua

Tahap kedua adalah pengembangan solusi berdasarkan prinsip desain yang ada dan inovasi teknologi. Konstruk dan isi sistem pelaporan hazard dan manajemen risiko keselamatan berbasis web yang akan didesain diperoleh melalui diskusi 
dengan Subject Matter Expert (SME). Informasi yang diperoleh kemudian digunakan untuk merancang sistem tersebut. Peneliti merancang database serta desain antarmuka pengguna. Database dirancang menggunakan MySQL dan desain antarmuka yang digunakan adalah Bootstrap 4 Template. Sistem ini dikembangkan menggunakan PHP sebagai program bahasa dengan bantuan CodeIgniter sebagai frameworknya.

\section{c. Tahap Ketiga}

Tahap ketiga adalah siklus berulang pengujian dan perbaikan sistem. Peneliti dan praktisi secara berkala menguji fungsi sistem dan jika ada bug maka peneliti akan memperbaiki masalah tersebut. Setelah desain selesai, peneliti mengundang manajemen bandara untuk melakukan tes penerimaan pengguna. Peneliti mempresentasikan sistem yang telah dikembangkan dan menunjukkan setiap fungsi dalam sistem kepada pengguna. Setiap umpan balik dari pengguna yang mengharuskan adanya perbaikan menjadi dasar untuk perbaikan, dan siklus iteratif akan berulang sampai pengguna merasa puas dengan hasil tes. Siklus iterasi berakhir di sana dan sistem itu siap dirilis.

\section{d. Tahap Keempat}

Tahap keempat adalah refleksi untuk menghasilkan prinsip desain dan meningkatkan sistem. Pada tahap ini peneliti mengedarkan kuesioner untuk mengetahui persepsi pengelola bandara terhadap sistem pelaporan hazard dan manajemen risiko keselamatan berbasis web pada aspek-aspek sebagai berikut: 1) manfaat aplikasi,
2) kesesuaian dengan kebutuhan,

3) kemudahan pengoperasian sistem,

4) desain antarmuka,

5) fitur untuk sistem secara keseluruhan,

6) fitur antarmuka pengguna,

7) fitur untuk antarmuka administrator , dan

8) keefektifan sistem.

Susunan kuesioner dapat dilihat pada Tabel 2.

\section{Instrument penelitian}

Instrument penelitian yang digunakan pada penelitian ini terdiri dari tiga jenis yakni wawancara, checklist (lihat Tabel 1), kuesioner untuk melihat persepsi pengguna produk (Lihat tabel 2). Instrument tersebut disusun berdasarkan kerangka teori yang telah di uji keabsahanya oleh expert validator baik oleh praktisi dan pakar dibidang safety manajemen system.

\section{Analisis Data}

Peneliti mengumpulkan data awal dengan menggunakan beberapa instrumen yakni wawancara, catatan lapangan dan kuesioner. Wawancara bertujuan untuk memperoleh analisis kebutuhan yang dilakukan dengan para expert dan praktisi kemudian dilakukan daftar periksa (lihat tabel 1) untuk memperoleh informasi mengenai standar pelaksanaan yang seharusnya dengan implementasi di lapangan sehingga diperoleh gap. Kemudian setelah ditemukan gap melalui penelitian awal, peneliti selanjutnya melakukan pengembangan produk berdasarkan gap yang ditemukan. Kuesioner kemudian menjadi intrumen 
Pengembangan Sistem Pelaporan Hazard Dan Manajemen Risiko Keselamatan Berbasis Web pada Bandar Udara

terakhir untuk memperoleh persepsi para pengguna produk untuk dilakukan pengembangan selanjutnya (lihat tabel 2). Dengan demikian, jenis data yang diperoleh terdiri dari dua kategori yakni data kualitatif dan kuantitatif. Data kualitatif berupa hasil pengamatan dan wawancara dideskripsikan secara explorasi sementara data kuantitatif disajikan berdasarkan statistik deskriptif yang kemudian dijelaskan secara kualitatif .

Tabel 1: Daftar periksa Identifikasi Hazard and Manajemen Risiko Keselamatan

\begin{tabular}{|c|c|c|c|}
\hline Item & Questions & Response & Comments \\
\hline \multicolumn{4}{|c|}{ 1. Hazard Identification } \\
\hline 1.1 & $\begin{array}{l}\text { Does the RST have a formal safety data } \\
\text { collection and processing system for } \\
\text { documenting operational hazards? }\end{array}$ & $\begin{array}{l}\square \text { Yes } \\
\square \text { No }\end{array}$ & \\
\hline 1.2 & $\begin{array}{l}\text { Do all RST members contribute to the formal } \\
\text { safety data collection and processing system } \\
\text { by sharing identified operational hazards? }\end{array}$ & $\begin{array}{l}\square \text { Yes } \\
\square \text { No }\end{array}$ & \\
\hline 1.3 & $\begin{array}{l}\text { Does the RST define and document specific } \\
\text { consequences for the operational hazards? }\end{array}$ & $\begin{array}{l}\square \text { Yes } \\
\square \text { No }\end{array}$ & \\
\hline \multicolumn{4}{|c|}{ 2. Safety Risk Management } \\
\hline 2.1 & $\begin{array}{l}\text { Does the RST have a formal process to } \\
\text { manage the operational risk? }\end{array}$ & $\begin{array}{l}\square \text { Yes } \\
\square \text { No }\end{array}$ & \\
\hline 2.2 & $\begin{array}{l}\text { As part of the risk management process, are } \\
\text { the consequences of the operational hazards } \\
\text { assessed in terms of probability and severity? }\end{array}$ & $\begin{array}{l}\square \text { Yes } \\
\square \text { No }\end{array}$ & \\
\hline 2.3 & $\begin{array}{l}\text { Is there a formalized process to determine the } \\
\text { level of risk the RST is willing to accept? }\end{array}$ & $\begin{array}{l}\square \text { Yes } \\
\square \text { No }\end{array}$ & \\
\hline 2.4 & $\begin{array}{l}\text { Does the RST develop risk mitigation } \\
\text { strategies to control the level of risk within } \\
\text { the operational environment? }\end{array}$ & $\begin{array}{l}\square \text { Yes } \\
\square \text { No }\end{array}$ & \\
\hline 2.5 & $\begin{array}{l}\text { Is there a formalized process for the RST to } \\
\text { make recommendations to applicable } \\
\text { stakeholders? }\end{array}$ & $\begin{array}{l}\square \text { Yes } \\
\square \text { No }\end{array}$ & \\
\hline 2.6 & $\begin{array}{l}\text { Is there a formalized process to document the } \\
\text { decisions made by the RST during the risk } \\
\text { management process? }\end{array}$ & $\begin{array}{l}\square \text { Yes } \\
\square \text { No }\end{array}$ & \\
\hline 2.7 & $\begin{array}{l}\text { Are the decisions made by the RST } \\
\text { periodically reviewed if the desired effect } \\
\text { was achieved by their } \\
\text { mitigations/recommendations? }\end{array}$ & $\begin{array}{l}\square \text { Yes } \\
\square \text { No }\end{array}$ & \\
\hline
\end{tabular}


Langit Biru: Jurnal Ilmiah Aviasi Vol. 14 No. 1 Februari 2021

ISSN (p) 1979-1534 ISSN (e) 2745-8695

Tabel 2: Kuesioner Persepsi Pengguna terhadap sistem yang dikembangkan

\begin{tabular}{cllllll}
\hline 1 & Application benefits (Manfaat aplikasi) & 1 & 2 & 3 & 4 & 5 \\
\hline 2 & Conformity with needs (Kesesuaian dengan kebutuhan) & 1 & 2 & 3 & 4 & 5 \\
\hline 3 & $\begin{array}{l}\text { Ease to operate the application (Kemudahan pengoperasian } \\
\text { aplikasi) }\end{array}$ & 1 & 2 & 3 & 4 & 5 \\
\hline 4 & Interface Design (Tampilan aplikasi) & 1 & 2 & 3 & 4 & 5 \\
\hline 5 & $\begin{array}{l}\text { Features for application as a whole (Fitur aplikasi secara } \\
\text { keseluruhan) }\end{array}$ & 1 & 2 & 3 & 4 & 5 \\
\hline 6 & Features for user (Fitur untuk user) & 1 & 2 & 3 & 4 & 5 \\
\hline 7 & Features for administrator (Fitur untuk administrator) & 1 & 2 & 3 & 4 & 5 \\
\hline 8 & $\begin{array}{l}\text { Effectiveness of the system in hazard reporting and safety risk } \\
\text { management (Keefektifan sistem untuk melaporkan hazard) }\end{array}$ & 1 & 2 & 3 & 4 & 5 \\
\hline
\end{tabular}

\section{Hasil dan Diskusi}

A. Desain sistem pelaporan hazard dan manajemen risiko keselamatan berbasis web

Hasil diskusi dengan Subject Matter Expert (SME) dan studi literatur menyarankan aspek-aspek yang dapat menjadi isi dari sistem pelaporan bahaya berbasis web antara lain :

1) Formulir Pelaporan Hazard

Hal-hal yang berpotensi sebagai hazard harus dilaporkan dengan mengisi formulir pelaporan hazard berbasis web yang terdiri dari poin-poin berikut:

a. Judul Laporan

Judul laporan diisi dengan nama hazard atau kejadian yang dilaporkan, misalnya: burung, FOD, tumpahan bahan bakar, dll.

b. Lokasi Kejadian/Isu keselamatan Lokasi kejadian/isu keselamatan diisi dengan nama lokasi ditemukannya atau terjadinya hazard/kejadian/isu keselamatan, misal: runway 09 , runway 27 , taxiway N3, apron, dll.

c. Tanggal dan Waktu Kejadian/Isu keselamatan
Tanggal dan waktu kejadian/isu keselamatan diisi dengan tanggal dan waktu kejadian/ isu keselamatan tersebut terjadi. Pelapor dapat memilih tanggal dan waktu dari kalender yang disediakan, misalnya: 30-07-2018 14:35.

d. Klasifikasi Kejadian/Isu keselamatan

Klasifikasi kejadian/isu keselamatan diisi dengan memilih salah satu klasifikasi berikut:

- Fasilitas

- Prosedur

- Sumber daya manusia

- Bahaya Satwa Liar/Hewan

- Balon/ Layanglayang/Drone/Laser

- Lainnya

e. Jenis Kejadian

Jenis kejadian diisi dengan memilih salah satu dari jenis kejadian berikut:

- Hazard

- Near-miss

- Incident

- Accident 
Pengembangan Sistem Pelaporan Hazard Dan Manajemen Risiko Keselamatan Berbasis Web pada Bandar Udara

f. Foto temuan

Pelapor dapat mengunggah foto temuan sebagai bukti laporan. Pelapor dapat mengunggah 2 (dua) foto atau lebih sekaligus.

g. Deskripsi

Kejadian/Isu
Pelapor dapat mendeskripsikan kejadian/isu keselamatan secara rinci.

h. Nama

Untuk mengisi nama pelapor tidak perlu menggunakan nama asli, dan itulah yang dianjurkan. Nama bisa diisi dengan "Anonymous".

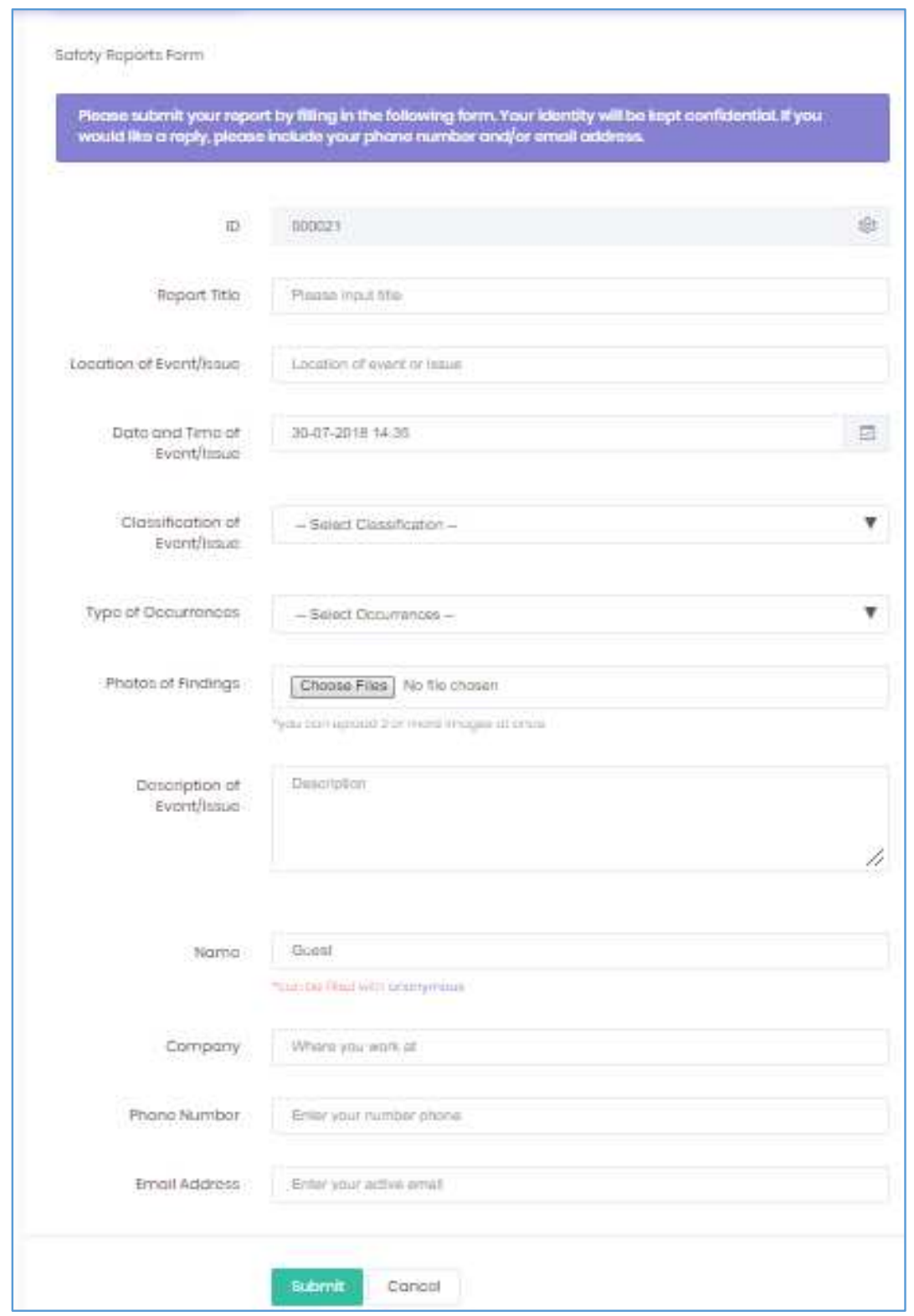

Gambar 2 : Formulir pelaporan hazard 


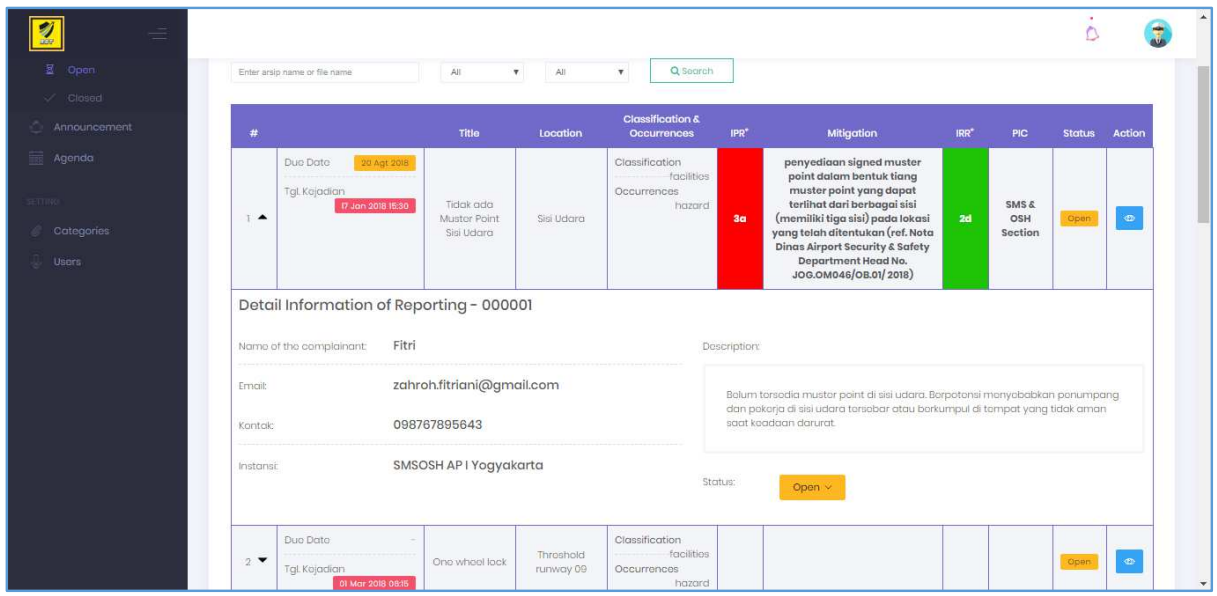

Gambar 3 : Halaman manajemen risiko keselamatan

i. Perusahaan

Perusahaan diisi dengan nama perusahaan tempat pelapor bekerja.

j. Nomor telepon

Nomor telepon diisi dengan nomor telepon pelapor. Nomor telepon diperlukan bagi administrator untuk menghubungi pelapor jika diperlukan rincian lebih lanjut.

k. Alamat email

Alamat email diisi dengan alamat email pelapor. Alamat email diperlukan untuk mengirim tanggapan/umpan balik.

Formulir pelaporan hazard dapat dilihat pada gambar 2 .
2) Manajemen Risiko Keselamatan

Pada Halaman Administrator, seorang administrator dapat mengelola laporan hazard dengan menentukan tingkat probabilitas (probability) kejadian dan tingkat keparahan (severity) dari konsekuensinya, menentukan mitigasinya, indeks risiko residual dan status laporannya. Gambar 3 menunjukkan halaman dimana administrator dapat mengelola laporan hazard dan risikonya.

Matriks penilaian risiko yang telah disepakati oleh bandara dan para pemangku kepentingan dapat dilihat pada tabel 3 .

Tabel 3 : Matriks penilaian risiko

\begin{tabular}{|l|c|c|c|c|c|}
\hline \multirow{2}{*}{ RISK } & \multicolumn{5}{|c|}{ SEVERITY OF CONSEQUENCES } \\
\cline { 2 - 6 } PROBABILITY & $\begin{array}{c}\text { Catastrophic } \\
\mathrm{A}\end{array}$ & $\begin{array}{c}\text { Hazardous } \\
\mathrm{B}\end{array}$ & $\begin{array}{c}\text { Major } \\
\mathrm{C}\end{array}$ & $\begin{array}{c}\text { Minor } \\
\mathrm{D}\end{array}$ & $\begin{array}{c}\text { Negligible } \\
\mathrm{E}\end{array}$ \\
\hline Frequent 5 & $5 \mathrm{~A}$ & $5 \mathrm{~B}$ & $5 \mathrm{C}$ & $5 \mathrm{D}$ & $5 \mathrm{E}$ \\
\hline Occasional 4 & $4 \mathrm{~A}$ & $4 \mathrm{~B}$ & $4 \mathrm{C}$ & $4 \mathrm{D}$ & $4 \mathrm{E}$ \\
\hline Remote 3 & $3 \mathrm{~A}$ & $3 \mathrm{~B}$ & $3 \mathrm{C}$ & $3 \mathrm{D}$ & $3 \mathrm{E}$ \\
\hline Improbable 2 & $2 \mathrm{~A}$ & $2 \mathrm{~B}$ & $2 \mathrm{C}$ & $2 \mathrm{D}$ & $2 \mathrm{E}$ \\
\hline $\begin{array}{l}\text { Extremely } \\
\text { Improbable 1 }\end{array}$ & $1 \mathrm{~A}$ & $1 \mathrm{~B}$ & $1 \mathrm{C}$ & $1 \mathrm{D}$ & $1 \mathrm{E}$ \\
\hline
\end{tabular}


Pengembangan Sistem Pelaporan Hazard Dan Manajemen Risiko Keselamatan Berbasis Web pada Bandar Udara

Indeks probabilitas (probability) risiko berkisar dari Frequent (5), Occasional (4), Remote (3), Improbable (2), dan Extremely Improbable (1). Sedangkan indeks keparahan (severity) konsekuensi berkisar dari Catastrophic (A), Hazardous (B), Major (C), Minor (D), dan Negligible (E). Keputusan untuk menilai domain risiko diklasifikasikan menjadi tiga domain yaitu: Acceptable, Tolerable (dengan mitigasi), dan Unacceptable Risks. Dalam matriks tersebut terdapat kode warna yang menggambarkan setiap domain yaitu hijau untuk Acceptable, kuning untuk Tolerable, dan merah untuk Unacceptable. Sistem akan secara otomatis menyesuaikan kode warna ketika administrator memutuskan indeks risiko hazard yang dilaporkan.

3) Mitigasi

Masih di halaman administrator, administrator perlu memutuskan rencana mitigasi, status laporan, dan indeks risiko residual. Mitigasi adalah tindakan preventif atau korektif yang perlu dilakukan untuk menghilangkan hazard. Status laporan diisi terbuka (open) jika belum ada mitigasi yang dilakukan, dan ditutup (closed) setelah dilakukan mitigasi. Indeks risiko residual harus diukur dengan melihat indeks risiko hazard setelah dilakukan mitigasi.

\section{B. Uji Penerimaan Pengguna}

Responden pada pengujian penerimaan produk terdiri dari 10 orang dari manajemen Bandara Internasional Adisutjipto Yogyakarta yang terdiri dari Airport Duty Manager, Airport Operation Department Head, Airport
Safety and Security Department Head, Airport Readiness Department Head, SMS \& OSH Section Head, Quality and Risk Management Section Head, 1 orang staf QRM, dan 3 orang staf SMS \& OSH. Pengujian Penerimaan produk dilaksanakan pada tanggal 21 Agustus 2018.

Uji Penerimaan Pengguna dilakukan dengan menguji setiap fungsi sistem pelaporan hazard dan manajemen risiko keselamatan berbasis web. Peneliti dengan disaksikan para responden menguji fungsi tersebut dan hasilnya menunjukkan bahwa semua fungsi berjalan dengan baik tanpa ada bug yang ditemukan selama pengujian. Namun, ada tanggapan dari pengelola bandara sebagai berikut:

- Keamanan aplikasi harus ditingkatkan untuk melindungi laporan keselamatan dari akses yang tidak sah.

- Penambahan tanda bintang pada field yang wajib diisi pada formulir laporan.

Umpan balik tersebut digunakan untuk menyempurnakan sistem dalam hal keamanan sistem dan penambahan tanda bintang untuk bidang wajib yang harus diisi pada formulir pelaporan. Sedangkan untuk keamanan aplikasi, sistem sudah dirancang sangat aman karena sistemnya terenkripsi. Hanya mereka yang memiliki kata sandi yang dapat mengakses aplikasi. File dan dokumen hanya dapat diakses oleh mereka yang diberi akses. Namun, ada sesuatu yang bisa dilakukan untuk meningkatkan keamanan. Pada awalnya, sistem dirancang untuk dua (2) pengguna yaitu guest dan administrator. Guest adalah anggota RST yang diberi 
kata sandi untuk mengakses formulir pelaporan dan safety library. Administrator adalah orang yang mengatur sistem. Untuk menambahkan lebih banyak lapisan pada keamanan sistem, sekarang sistem dirancang untuk tiga (3) pengguna yaitu guest, user, dan administrator dengan hak akses yang berbeda. Sedangkan untuk field yang wajib diisi, telah ditambahkan tanda bintang pada judul laporan, lokasi kejadian/isu keselamatan, tanggal dan waktu kejadian/isu keselamatan, klasifikasi kejadian/isu keselamatan, jenis kejadian, nomor telepon dan alamat email.

Desain yang telah direvisi dilakukan pengujian lagi kepada manajer keselamatan dan hasilnya menunjukkan bahwa pengguna merasa puas. Iterasi berakhir di sana dan sistem tersebut siap dirilis.

\section{Persepsi Pengguna terhadap sistem yang dikembangkan}

Kuesioner yang diberikan untuk mengetahui persepsi pengelola bandara terhadap sistem yang dikembangkan dianalisis secara deskriptif. Penyajian data hasil kuisioner dapat dilihat pada Tabel 4.
Dapat disimpulkan bahwa pelaporan hazard dan manajemen risiko keselamatan berbasis web yang dikembangkan oleh peneliti bekerjasama dengan praktisi keselamatan bandara berguna, sesuai dengan kebutuhan, dan efektif untuk pelaporan hazard dan pengelolaan risiko keselamatan di bandara.

\section{Kesimpulan}

Studi penelitian ini telah memberikan penjelasan tentang perlunya pelaporan hazard dan manajemen risiko keselamatan berbasis web di area penerbangan. Melalui model Amiel dan Reeves (2008), sistem pelaporan hazard dan manajemen risiko keselamatan berbasis web yang diusulkan telah berhasil dianggap sebagai sistem yang ideal dan dapat diterapkan untuk menyediakan portal sistem pelaporan baru. Namun, terlepas dari itu, sistem tersebut mungkin memiliki kelemahan pada keamanan dan kerahasiaan laporan keselamatan. Oleh karena itu, kerahasiaan harus menjadi hal yang penting dalam sistem ini. Manajemen bandara harus secara teratur mengubah kata sandi sistem jika ada perpindahan karyawan ke tempat kerja yang berbeda, yang pasti terjadi dari waktu ke waktu.

Tabel 4 : Penyajian Data Hasil Kuesioner

\begin{tabular}{|c|c|c|c|c|c|c|c|c|c|c|c|c|}
\hline \multirow{2}{*}{ No } & \multirow{2}{*}{$\begin{array}{c}\text { State- } \\
\text { ments }\end{array}$} & \multirow{2}{*}{$\mathbf{N}$} & \multicolumn{2}{|c|}{$\begin{array}{c}\text { Strongly } \\
\text { Disagree }\end{array}$} & \multicolumn{2}{|c|}{ Disagree } & \multicolumn{2}{|c|}{ Neutral } & \multicolumn{2}{|c|}{ Agree } & \multicolumn{2}{c|}{ Strongly Agree } \\
\cline { 4 - 13 } & & Freq & $\%$ & Freq & $\%$ & Freq & $\%$ & Freq & $\%$ & Freq & $\%$ \\
\hline 1 & S1 & 10 & 0 & $0 \%$ & 0 & $0 \%$ & 0 & $0 \%$ & 1 & $10 \%$ & 9 & $90 \%$ \\
\hline 2 & S2 & 10 & 0 & $0 \%$ & 0 & $0 \%$ & 0 & $0 \%$ & 3 & $30 \%$ & 7 & $70 \%$ \\
\hline 3 & S3 & 10 & 0 & $0 \%$ & 0 & $0 \%$ & 1 & $10 \%$ & 4 & $40 \%$ & 5 & $50 \%$ \\
\hline 4 & S4 & 10 & 0 & $0 \%$ & 0 & $0 \%$ & 1 & $10 \%$ & 1 & $10 \%$ & 8 & $80 \%$ \\
\hline 5 & S5 & 10 & 0 & $0 \%$ & 0 & $0 \%$ & 0 & $0 \%$ & 3 & $30 \%$ & 7 & $70 \%$ \\
\hline 6 & S6 & 10 & 0 & $0 \%$ & 0 & $0 \%$ & 0 & $0 \%$ & 2 & $20 \%$ & 8 & $80 \%$ \\
\hline 7 & S7 & 10 & 0 & $0 \%$ & 0 & $0 \%$ & 0 & $0 \%$ & 3 & $30 \%$ & 7 & $70 \%$ \\
\hline 8 & S8 & 10 & 0 & $0 \%$ & 0 & $0 \%$ & 0 & $0 \%$ & 6 & $60 \%$ & 4 & $40 \%$ \\
\hline
\end{tabular}


Pengembangan Sistem Pelaporan Hazard Dan Manajemen Risiko Keselamatan Berbasis Web pada Bandar Udara

\section{Daftar Pustaka}

Airports Council International World Safety \& Technical Standing Committee. (2014). Runway Safety Handbook ( $1^{\text {st }}$ edition). Montreal, Canada: ACI World.

Amiel, T., \& Reeves, T. C. (2008). Design-Based Research and Educational Technology: Rethinking Technology and the Research Agenda. Educational Technology \& Society, 11 (4), 29-40.

Ellis, Timothy and Levy, Yair. (2010). A Guide for Novice Researchers: Design and Development Research Methods. Proceedings of Informing Science \& IT Education Conference (InSITE).

Hevner, Alan R., March, Salvatore T., Park, Jinsoo ., and Ram, Sudha. (2004). Design Science in Information Systems Research. MIS Quarterly Vol. 28 No. 1, pp. 75-105.

International Civil Aviation Organization. (2013). Doc 9859, Safety Management Manual (SMM) $3^{\text {rd }}$ edition. Montreal, Canada : ICAO.

International Civil Aviation Organization. (2013). Doc 9870, Manual on the Prevention of Runway Incursions. Montreal, Canada : ICAO.

International Civil Aviation Organization. (2015). Runway Safety Team Handbook (2nd edition). Montreal, Canada : ICAO.

International Civil Aviation Organization. (2016). Annex 19 to the Convention of
International Civil Aviation

Safety Management second edition. Montreal, Canada : ICAO.

Ministry of Transportation. (2017). Civil Aviation Safety Regulation Part 19 Safety Management System. Indonesia: Ministry of Transportation Republic of Indonesia.

Ministry of Transportation. (2017). Ministry of Transportation Regulation Number: PM 83 Year 2017 on Civil Aviation Safety Regulations Part 139 about Aerodrome. Indonesia: Ministry of Transportation Republic of Indonesia.

Nikitha, G.V., Anithasree C., Roopa L., Priya, T. L., and Senbagavalli M. (2018). Implementation Of Online Crime Reporting System. International Journal of Research Review In Engineering And Management (IJRREM) Volume -2, Issue -4. ISSN No (online): Application No: 17320. RNI-Application No 2017103794.

Nunamaker, J. R., Chen, J. F., \& Purdin, T. D. M. (1991). Systems development in information systems research. Journal of Management Information Systems, 7(3), 89-106

Peffers, Ken., Tuunanen, Tuure., Rothenberger, Marcus A., and Chatterjee, Samir. (2007). A Design Science Research Methodology for Information Systems Research. Journal of Management Information 
Langit Biru: Jurnal Ilmiah Aviasi Vol. 14 No. 1 Februari 2021

ISSN (p) 1979-1534 ISSN (e) 2745-8695

Systems, Volume 24 Issue 3, Winter 2007-8, pp. 45-78.

Peters, Cheryl L., Rennekamp, Denise., and Bowman, Sally. (2008). An Online Reporting System for Evaluating Multi-Site Parenting Education Programs. Journal of Extension. ISSN 1077-5315.

Richey, Rita C. (2013). Encyclopedia of Terminology for Educational Communications and Technology. New York: Springer Science + Business Media.

Setyawan, Supanji., Priyono, Nuwun., and Iswanaji, Khaidir. (2017). Developing Model of EBudgeting and E-Reporting System on the Management of Village Fund Finance. Jurnal Dinamika Akuntansi Vol. 9, No. 1.

Wang, Feng and Hannafin, M. J., (2005). Design-based research and technology-enhanced learning environments.

Educational Technology Research and Development, 53(4), 5-23. 